\title{
Cerebellar meningeal melanocytoma associated with nevus of Ota
}

\author{
An extremely rare case
}

Figure 1 Photograph of the patient and preoperative brain MRI and CT

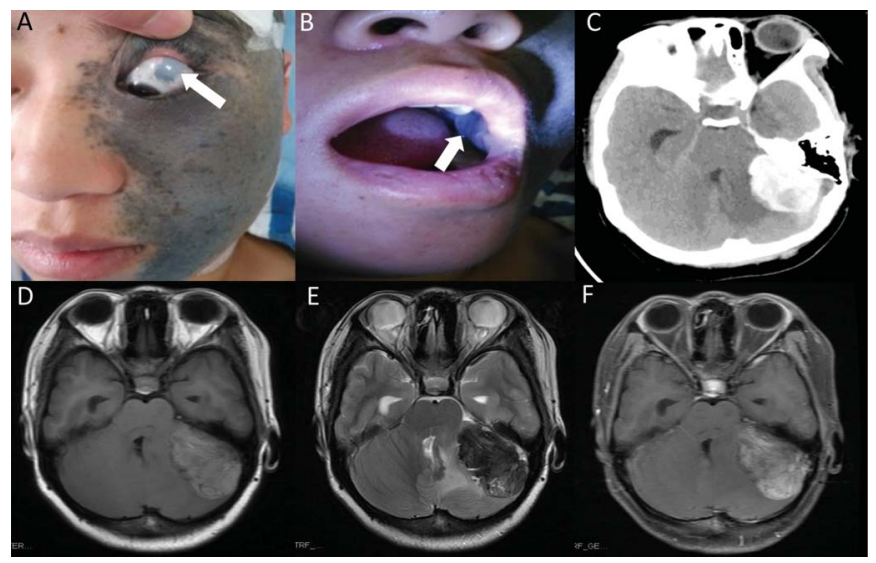

Physical examination found a congenital irregular grayish-blue macular pigmented nevus located in the territory of the left trigeminal nerve (A); bluish pigmentation of ipsilateral sclera and oral mucosal membrane were also observed (A, B, arrow). Axial CT of the head scan showed a heterogeneous hyperdense mass surrounded by a little slightly hyperdense shadow and flake edema (C). Axial MRI disclosed a slightly T1-hyperintense and T2-hypointense lesion with a welldemarcated border adjacent to the brainstem $(D, E)$, and the posterior part of the tumor enhanced obviously after gadolinium administration (F).

A 20-year-old woman presented with a 2-day history of headache. She had a congenital grayish-blue pigmented nevus on her left side face, which involved ipsilateral sclera and oral mucosal membrane, diagnosed as nevus of Ota (figure 1, A and B). Neuroradiologic manifestation revealed a lesion in the left cerebellar hemisphere, the etiology of the presenting tumor apoplexy (figure 1, C-F). A left cerebellar hemisphere craniotomy was performed. A well-defined black lesion involved dura mater to the pia mater and was firmly attached to the cerebellar tentorium (figure 2, A and B). Histopathologic examination confirmed a meningeal melanocytoma. Postoperative CT demonstrated total tumor resection. ${ }^{1}$

Figure 2 Intraoperative findings

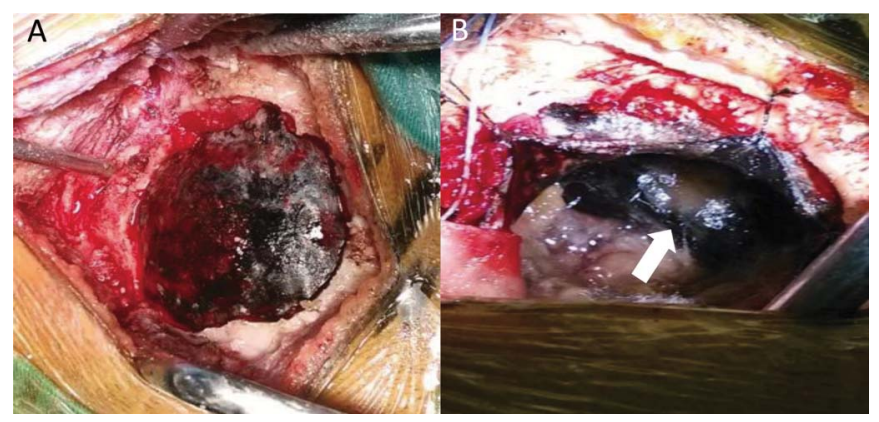

The well-defined, soft, friable and black lesion involved dura mater to the arachnoid membrane and the pia mater (A, B), and it was firmly attached to the tentorium of cerebellum ( $B$, arrow). 
Hongxu Chen, MD, * Wenke Liu, MD, * Si Zhang, MD, Jianguo Xu, MD, Xuhui Hui, MD

*These authors contributed equally to this work and should be considered co-first authors.

From West China Hospital, Sichuan University, China.

Author contributions: All authors were involved in clinical care and investigative workup of the patient. Xuhui Hui provided pictures of the patient and drafted and revised the manuscript. Hongxu Chen and Wenke Liu performed the patient follow-up and drafted and revised the manuscript. Si Zhang and Jianguo Xu were responsible for the study concept and revised the manuscript for intellectual content.

Study funding: No targeted funding reported.

Disclosure: The authors report no disclosures relevant to the manuscript. Go to Neurology.org for full disclosures.

Correspondence to Dr. Hui: huixuhui6362@163.com

1. Munoz-Hidalgo L, Lopez-Gines C, Navarro L, et al. BRAF V600E mutation in two distinct meningeal melanocytomas associated with a nevus of Ota. J Clin Oncol 2014;32:e72-e75.

\section{Quality CME. Expert Faculty. Improved Patient Care.}

\section{Register Today for the AAN Fall Conference!}

Register today for the 2015 AAN Fall Conference, set for October 16 through 18 at The Cosmopolitan of Las Vegas. Learn from expert faculty as they present the latest clinical and practice management advances to help you stay current, provide the best patient care, and keep your practice thriving-all while earning up to 18.75 CME in three days! New for 2015-four courses now qualify for self-assessment (SA) CME (get up to $15 \mathrm{SA}$ credits total).

Early registration and hotel discounts end September 10. Visit AAN.com/view/Fall to learn more and register today.

\section{Enjoy Neurology ${ }^{\circledR}$ Clinical Practice on your iPad ${ }^{\circledR}$}

The same information so critical to your practice is now brought to you on the $\mathrm{iPad}^{\circledR}$. This dynamic app optimizes the best in digital technology to enhance the reading experience with article-sharing features, multimedia, links, and more.

\section{Enjoy the benefits:}

- Easy-to-read articles you can share via email and social media

- Adjustable text sizing with "pinch and zoom" technology

- Engaging multimedia videos, images, and data supplements

- Ability to store downloaded issues

- Convenient notification when a new issue is available

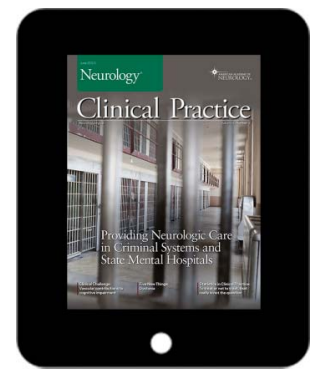

AAN members - enjoy Full Access to every issue on your $\mathrm{iPad}^{\circledR}$. If you are not yet a member, download the app and GET THE LATEST ISSUE FREE! (Go to http://bit.ly/NCPapp for details.) 


\section{Neurology}

\section{Cerebellar meningeal melanocytoma associated with nevus of Ota: An extremely rare case}

Hongxu Chen, Wenke Liu, Si Zhang, et al. Neurology 2015;85;555-556

DOI 10.1212/WNL.0000000000001837

\section{This information is current as of August 10, 2015}

\section{Updated Information \& Services}

References

Subspecialty Collections

Permissions \& Licensing

Reprints including high resolution figures, can be found at: http://n.neurology.org/content/85/6/555.full

This article cites 1 articles, 1 of which you can access for free at: http://n.neurology.org/content/85/6/555.full\#ref-list-1

This article, along with others on similar topics, appears in the following collection(s):

All Headache

http://n.neurology.org/cgi/collection/all_headache All Imaging http://n.neurology.org/cgi/collection/all_imaging Primary brain tumor http://n.neurology.org/cgi/collection/primary_brain_tumor

Information about reproducing this article in parts (figures,tables) or in its entirety can be found online at:

http://www.neurology.org/about/about_the_journal\#permissions

Information about ordering reprints can be found online:

http://n.neurology.org/subscribers/advertise

Neurology ${ }^{\circledR}$ is the official journal of the American Academy of Neurology. Published continuously since 1951, it is now a weekly with 48 issues per year. Copyright @ 2015 American Academy of Neurology. All rights reserved. Print ISSN: 0028-3878. Online ISSN: 1526-632X.

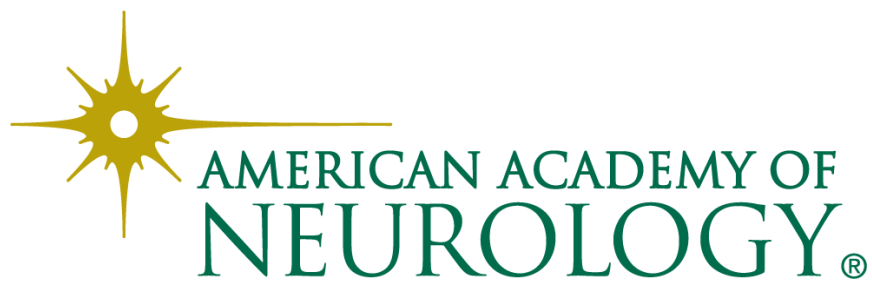

